УДК 1(091)

DOI https://doi.org/10.24866/1997-2857/2021-3/104-108

\title{
Л.Е. Шапошников*
}

\section{В.В. РОЗАНОВ О НЕОБХОДИМОСТИ ДЛЯ РОССИИ «НАЦИОНАЛЬНОЙ ШКОЛЫ»}

В статье рассматриваются взгляды В.В. Розанова на проблемы национальной школы. Ориентация отечественного образования на западные стандарты, по его мнению, несет угрозу потери национальной идентичности. Обращение к базисным ценностям отечественной духовной традиции должно стать необходимым элементом школьного обучения. Более того, на качество образовательного процесса неизбежно влияет и статус педагога, в связи с чем в своих работах В.В. Розанов формулирует систему мер по его повышению, а также последовательно критикует политику бюрократизации образования. Автор подчеркивает важность и актуальность идей В.В. Розанова в современных российских реалиях.

Ключевые слова: В.В. Розанов, философия образования, образовательная система, национальные традиции

Vasily Rozanov on the necessity of the «national school» for Russia. LEV E. SHAPOSHNIKOV (Minin Nizhny Novgorod State Pedagogical University)

The paper analyses the views of Vasily Rozanov on the issue of national school. The scholar believed that if domestic education follows the Western educational standards, prioritizing those, the national identity of Russia will be lost. Thus, traditional values and expertise should be the fundamental basis of secondary education. Moreover, the status of a teacher inevitably affects the quality of the educational experience, that is why Rozanov suggested a number of ways to enhance it. In his works, the philosopher also heavily criticized the bureaucracy in education. The paper highlights the importance and relevance of Rozanov's ideas for modern Russia.

Keywords: Vasily Rozanov, philosophy of education, educational system, national traditions

Анализируя российскую систему образования и воспитания, Василий Васильевич Розанов отмечает ее определенные успехи: «Мы имеем дидактику и ряд дидактик; мы имеем методику и ряд методик; мы имеем вообще педагогику как теорию». Но в России нет того, что можно назвать «философией воспитания и образования». Ее предметом является и содержательное раскрытие самих этих феноменов, и определение их значения «в ряду остальных культурных факторов», наконец, необходимо выявить отношение задач воспитания и образования «к вечным чертам человеческой природы и целями истории». Без решения этих методологических задач само по себе усовершенствование методик и дидактических приемов преподавания

* ШАПОШНИКОВ Лев Евгеньевич, доктор философских наук, президент Нижегородского государственного педагогического университета им. Козьмы Минина.

E-mail: shaposhnikov_le@mininuniver.ru

(C) Шапошников Л.Е., 2021 
даст результат «скорее отрицательный, нежели положительный» [5, с. 621]. Философия воспитания и образования, по мнению В.В. Розанова, должна обратить особое внимание на три «первенствующих принципа», а именно: национальности, семейности и практицизма. Для избранной нами темы имеет значение первый принцип, на его анализе мы и остановимся.

Проблема русской, национальной школы является для мыслителя одной из основных. Он не приемлет космополитическую систему, считая, что создание человека вне духа своей культуры, синтетически собранного из элементов всех цивилизаций, есть идея крайне искусственная и под этой всемирностью «нет гражданина» [5, c. 368]. В то же время в российской гимназии смешиваются три разнородные сферы знания: во-первых, классические языки и античная культура; во-вторых, христианское вероучение и история; в-третьих, собрание «точных, внешних познаний человека о себе и о природе». Особенно много вопросов вызывает засилье в гимназическом образовании классических языков. Во всех сферах деятельности, где «теория смешивается с практикой», реформы происходят «на основании предварительного испытания», однако, «к глубокому несчастью судеб народного образования в России, этот здравый и осторожный путь никогда не был у нас школьным путем» [4, с. 562]. Данное замечание в полной мере относится и к «приказному классицизму», который вопреки мнению общественности был принят «не культурно, а как “бумага к исполнению"».

В связи с этим В.В. Розанов приводит интересные факты, относящиеся к «ярому поклоннику» классического образования Д.А. Толстому. Оказывается, сам реформатор гимназий «не был вовсе отличным классиком» и даже брал уроки по древним языкам, чтобы «хотя поверхностно ознакомиться с рекомендуемою им вещью» $[4$, с. 236]. Более того, по мере реализации министерских установок становилось все более ясным, что вводится в гимназиях «не столько классицизм, сколько германизм». Но если для немцев и других западноевропейцев «латинский быт, и строй, и культура, и, следовательно, образование» есть элементы национальной традиции, то мы, русские, «ничего оттуда не взяли непосредственно, а если что взяли, то через немцев и французов» [4, с. 610]. В результате гимназисты «остались скорее совсем без образования, чем с классическим образованием».
Поэтому необходимо вернуть школу к национальным традициям и поставить «на первом месте Отечествоведение». Вместо безжизненных грамматических схем и бездумной зубрежки ученики будут изучать отечественную историю, географию своей страны, фольклор, русскую культуру и особенно литературу. При этом обучение не должно «отгораживать» гимназию от мирового культурного и образовательного процесса, и для этих целей следует более основательно овладеть современными европейскими языками. Реализация программ, связанных c «отечествоведением», позволит преодолеть «культурное рабство» перед Западом и занять в отношении его положение «сотрудника, собрата, который прежде всего не теряет уважения к своему “я"» [4, с. 611].

Необходимость преодоления «мертвящего классицизма», как отмечает В.В. Розанов, стала осознаваться и правительством. Так, 1 августа 1900 г. появился циркуляр Министерства народного просвещения о том, что «экстемпоралии как средство учебного контроля должны быть устранены из школьной практики, как не достигавшие цели». Мудреное латинское слово extemporalis означает классное письменное упражнение, состоящее в переводе с родного языка на иностранный без предварительной подготовки. Притом эти работы, выполненные на греческом или латинском языках, проверялись не только гимназическими учителями, но и вышестоящим начальством. Более того, гимназии учебного округа располагались ежегодно по ранжиру исходя из «качества письменных работ». Отсюда постоянная муштра гимназистов, в том числе и во вред их здоровью, которое, как едко замечает мыслитель, относилось к «вещи не учитываемой». Теперь же письменные испытания по древним языкам отменялись, но остались «в прежней силе» экзамены по математике, русскому языку и словесности. Однако они были для гимназистов и понятнее, и мотивированнее и не вызывали у них такого негативизма, как греческий и латинский языки.

Отвечая на упреки противников национальной школы, утверждающих «недостаточность собственно русских начал для образования», В.В. Розанов справедливо отмечал, что подобные рассуждения «пусты и ничтожны уже потому, что мы этих начал никогда не применяли в школе» [4, с. 362]. Более того, совершенно необоснованным, с точки зрения мыслителя, является стремление представить «самобыт- 
ные начала в образовании» как начала отсталые, консервирующие «отечественное невежество»: в среднем общем образовании «все должно быть национально, но национальное должно быть и всемирно удовлетворительно». Для того, чтобы достичь этой цели, необходимо «серьезное и внимательное изучение отечественных традиций, которое должно составить самый фундамент нашей школьной системы» [4, с. 362]. Русская культура и наука, отечественная педагогика достигли такого развития, при котором не только возможно, но и нужно ориентировать просвещение на развитие национальной школы. Этот вывод мыслителя актуален и сегодня, когда под лозунгами «отказа от отживших традиций» из школы изгоняются гуманитарные знания, формирующие национальное самосознание.

Наконец, Розанова волновала еще одна проблема, связанная с просвещением: какова роль государства в этой сфере? Историческое развитие России привело к особому значению государства и его органов в различных областях общественной жизни. В силу данного обстоятельства от Министерства народного просвещения многое зависит в «самочувствии российского образования». Однако высший орган управления просвещением можно назвать «министерством по поводу просвещения», так как «косвенные и скрытые его задачи господствовали и подавляли в нем прямые и открытые цели»: вместо решения главных проблем образования, связанных «с духом и культурой», со статусом учителя, с удовлетворением потребностей общества в «грамотных работниках», министерство «регулирует подробности», «вводит различные комбинации предметов», «регламентирует прием учеников в школу» и т.п. При этом оно в своей деятельности постоянно «сверяется с западными образцами», часто выбирая среди них для подражания отнюдь не лучшее. Поэтому, как замечает В.В. Розанов, «самый материал образования» в большинстве своем не русский и поэтому «незаметно и неуклонно» мы переделываем самую структуру русской души «на манер иностранного» [4, с. 114]. Мыслитель, анализируя деятельность министров просвещения в России, констатирует тот факт, что они не разделяли славянофильской ориентации. По его мнению, это удивительное явление, что «никогда даже опыта не было поставить во главе русского училищного дела человека традиций Киреевских, Хомякова, Аксаковых, Тютчева» [3, с. 339].
Образовательная система, как и общество в целом, подвержена изменениям, но надо понимать, что школа - это не просто «сумма порядков». Просвещение связано с духовными традициями, с уровнем развития культуры и науки, в силу этого «школа вырабатывается даже не веком, а веками» [2, с. 34]. В этой связи понятно, что стремление постоянно реформировать образование приводит к разрушению «устойчивости учебной системы». Вместо декларируемого реформаторами «ускорения прогресса» происходит «огромная задержка в развитии страны». Только благодаря сохранению образовательных традиций «вся страна получает устойчивую цель своих умственных напряжений». Славянофилы как раз и предлагали программу сохранения самобытных начал при проведении «образовательной политики», и данная установка близка В.В. Розанову. При этом еще раз отметим, что самобытность для него не означает отсталости, а, напротив, выступает базисом позитивного развития.

Анализируя российскую систему просвещения, В.В. Розанов уделяет особое внимание роли учителя в воспитании и образовании. По его мнению, «вопрос об учителе - это почти весь вопрос о школе, потому что учитель, собственно, и составляет школу» [4, с. 243]. Данная профессия одна из самых трудных, ибо она предполагает определенную «педагогическую умелость», получаемую в ходе обучения, и в то же время у человека должны быть задатки, «предрасположение» к этому виду деятельности». При этом одних умственных способностей мало, так как есть люди интеллектуально одаренные, но они «трудятся про себя и для себя». Учитель же должен обладать «духовным бескорыстием» и быть способным к синтезу с «заинтересованностью личностью ученика и содержанием предмета». В то же время современное положение школьного преподавателя вызывает в общественном мнении «насмешки и вражду». Мыслитель убежден, что при «такой молве об учителе» подлинное, «настоящее образование не может сложиться успешно» [4, c. 239]. Откуда же проистекает подобный взгляд на преподавателя? Гимназисты часто обвиняют своих наставников «в черствости, безжалостности, в формальном отношении к делу». Однако учитель в этом не виноват, ведь сама гимназия - это «сумма педагогических формальностей, без животворящего в них педагогического духа». Поэтому преподаватель не может в своей 
деятельности руководствоваться собственными внутренними установками, он «перепутан стальной паутиной тончайших регламентаций». Его профессиональная судьба во многом зависит от директора учебного заведения, который ведет себя как «администратор», а «отнюдь не педагог» [2, с. 38]. В силу этого стремление к улучшению «учебного дела» сводится к различным административным решениям, к «ужесточению правил», но эффективность подобных действий чрезвычайно низка. Конечно, в ходе организации учебного процесса определенные административные начала необходимы, но сами по себе они бессильны «создать какой-нибудь идеал, придать содержанию смысл, одухотворить форму». Следовательно, национальная образовательная система должна эволюционировать в сторону расширения прав учителя как в определении содержания урока, так и в повышении его социального статуса. Сейчас, подчеркивает мыслитель, назначение преподавателя на должность, его перемещение с одного места работы на другое, «способ произведения ревизий» подчеркивают полную зависимость педагога от «вышестоящих властей». В этой сфере, по мнению В.В. Розанова, требуется «умягчение нравов», которое должно состоять «в соблюдении большей деликатности в отношении человеческой личности» [2, с. 282].

Наконец, еще одна проблема, определяющая статус российского учителя, - это его материальное положение, связанное с объемом государственного финансирования образования в целом. К сожалению, ассигнования на эти цели выделяются по остаточному принципу, государство прежде всего заботится об армии и флоте. Однако без высокоразвитого просвещения Россия не сможет «стать духовно вооруженною страною, умственно мощною страною», а именно данные факторы выступают «основой армий и флотов» [1, с. 185].

Радикальное увеличение финансирования системы образования, с одной стороны, позволит увеличить численность школ, их разнообразие, а главное - сделать их доступными для всех детей, с другой - «денежная перемена» изменит весь нравственный климат школы, ибо «перед учениками будет стоять и сидеть не злой учитель, а добрый учитель!» [1, с. 273]. Потому что он перестанет думать «о пропитании семьи», о дополнительном заработке, о том, где взять средства на нужную литературу, как обустроить свой быт и т.п.
Итак, проблемы философии воспитания и образования находились в центре внимания В.В. Розанова. Живя на рубеже XIX и XX вв., он сумел рельефно показать слабые стороны российского просвещения и предложить пути его позитивного развития. Данное обстоятельство делает творчество мыслителя чрезвычайно востребованным при анализе современной системы образования. Его яркая апология национально ориентированной школы не утратила и сегодня своего значения. Наконец, обоснование необходимости повышения социального статуса учителя, улучшения его материального положения, преодоления министерского бюрократизма, осуждение «бездумного реформаторства» может служить программой неотложных мер по совершенствованию сегодняшнего школьного дела.

\section{СПИСОК ЛИТЕРАТУРЫ}

1. Розанов В.В. Собрание сочинений: в 30-ти т. Т. 17. В нашей смуте (Статьи 1908 г.). Письма к Э.Ф. Голлербаху. М.: Республика, 2004.

2. Розанов В.В. Розанов В.В. Собрание сочинений: в 30-ти т. Т. 19. Старая и молодая Россия (Статьи и очерки 1909 г.). М.: Республика, 2004.

3. Розанов В.В. Собрание сочинений: в 30-ти т. Т. 23. На фундаменте прошлого (Статьи и очерки 1913-1915 гг.). М.; СПб.: Республика; Росток, 2007.

4. Розанов В.В. Розанов В.В. Собрание сочинений: в 30-ти т. Т. 27. Юдаизм (Статьи и очерки 1898-1901 гг.). М.; СПб.: Республика; Росток, 2009.

5. Розанов В.В. Собрание сочинений: в 30-ти т. Т. 28. Эстетическое понимание истории (Статьи и очерки 1889-1897 гг.). Сумерки просвещения. М.; СПб.: Республика; Росток, 2009.

\section{REFERENCES}

1. Rozanov, V.V., 2004. Sobranie sochinenii: v 30-ti t. T. 17. V nashei smute (Stat'i 1908 g.). Pis'ma k E.F. Gollerbakhu [Collected works: in 30 volumes. Vol. 17. In our turmoil (Articles of 1908). Letters to E.F. Hollerbach]. Moskva: Respublika. (in Russ.)

2. Rozanov, V.V., 2004. Sobranie sochinenii: v 30-ti t. T. 19. Staraya i molodaya Rossiya (Stat'i i ocherki 1909 g.) [Collected works: in 30 volumes. Vol. 19. Old and young Russia (Articles and essays of 1909)]. Moskva: Respublika. (in Russ.)

3. Rozanov, V.V., 2007. Sobranie sochinenii: v 30-ti t. T. 23. Na fundamente proshlogo (Stat'i i 
ocherki 1913-1915 gg.) [Collected works: in 30 volumes. Vol. 23. On the foundation of the past (Articles and essays of 1913-1915)]. Moskva; Sankt-Peterburg: Respublika; Rostok. (in Russ.)

4. Rozanov, V.V., 2009. Sobranie sochinenii: v $30-$ ti t. T. 27. Yudaism (Stat'i i ocherki 1898-1901 gg.) [Collected works: in 30 volumes. Vol. 27. Judaism (Articles and essays of 1898-1901]. Moskva; SanktPeterburg: Respublika; Rostok. (in Russ.)
5. Rozanov, V.V., 2009. Sobranie sochinenii: v 30-ti t. T. 28. Esteticheskoe ponimanie istorii (Stat'i i ocherki 1889-1897 gg.). Sumerki prosveshcheniya [Collected works: in 30 volumes. Vol. 28. The aesthetic understanding of history (Articles and essays of 1889-1897). The twilight of enlightenment]. Moskva; Sankt-Peterburg: Respublika; Rostok. (in Russ.)

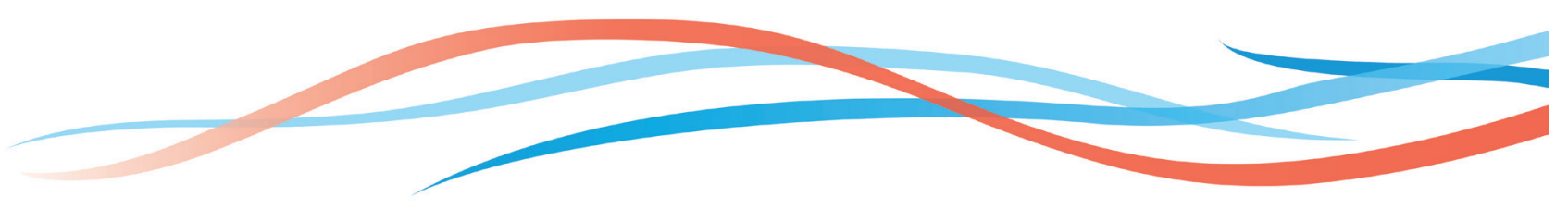

